\title{
O TRATAMENTO JAPONÉS E SEUS SIGNIFICADOS
}

Tae Suzuki

Um homem pode se comunicar por meio de gestos, de expressões faciais, de trejeitos. Assim, um sorriso pode transmitir a outrem a aprovação, a ternura, a alegria; um cenho franzido, a desaprovação, a preocupação, a desconfiança; as palmas da mão estendidas e voltadas para a outra pessoa, um sinal de alerta, um pedido de calma. A exceção de alguns desses meios - como o choro de uma criança que denuncia um estado de desconforto ou de indisposiçáo, ou o seu sorriso que comunica à mãe o seu bem-estar, a sua satisfação - a maioria repousa num código estabelecido pelo meio em que sāo utilizados e que é o resultado da sedimentação de costumes e valores culturais próprios.

No entanto, o meio mais utilizado para a comunicação é a palavra. O homem se serve primordialmente da palavra para expressar suas idéias, seus sentimentos, suas conviç̧ões, seus anseios, seu pensamento - é através delas que o homem se comunica com os outros e assim, participa e vive o seu meio. Mas a palavra não é tudo, ela nao basta por si. Como afirmam Ogden e Richards: "as palavras nada "significam" por si mesmas. ( ) Só quando um pensamento as usa é que elas representam alguma coisa ou, numa determinada acepção, têm "significado" Elas são instrumentos."(1)

As palavras passam a existir à medida em que têm um pensamento que as suporte. O pensamento, por sua vez, também não se encontra isolado, ele é o resultado de uma concorrência de valores institufdos e seguidos pelas pessoas que vivem em um determinado meio social e/ou cultural. Ao mesmo tempo em que as palavras existem enquanto expressão de algo, elas passam a ser o veículo de transmissão do significado desse algo, significado que, por sua vez, se apóia na 
experiência, nos valores, nas visões de mundo dos homens. É nessa função comunicativa e transmissora de idéias que as palavras ocupam lugar de destaque nas atividades humanas.

Assim como a palavra transmite e comunica, o tratamento é uma forma de transmitir a consideração do seu usuário por alguém. Qual a relação entre a palavra e o tratamento? Qual o significado do tratamento da lingua japonesa? São as propostas de especulação do presente trabalho.

O tratamento pode ser expresso de várias maneiras. Podemos demonstrar a nossa consideração por outrem com um simples inclinar ligeiro da cabeça, com um estender do braço para permitir a outrem que entre primeiro em um recinto, com um levantar-se da cadeira à chegada de terceiros, com o permanecer-se de pé esperando que o outro se acomode primeiro. E assim poderíamos enumerar uma série de regras de etiqueta, muitas das quais hoje em desuso mas vivas no nosso esp írito. São todos atos e atitudes que, de uma forma ou outra, manifestam a consideração de quem os pratica em relação a quem.

Podemos citar ainda outros atos que, embora nåo tão explicitamente quanto os citados, também são prova da consideração do seu agente em relação a terceiros. São, por exemplo, o eu esperar com que o outro termine a sua fala para iniciar a minha; 0 ralentar o ritmo da minha refeição a fim de que possa chegar à sobremesa mais ou menos ao mesmo tempo que um conviva mais falante; o desviar-me do caminho porque, embora mais curto, sei que aquele lugar traz recordaçø̃es desagradáveis ao meu acompanhante; o evitar pronunciar o nome de Fulano porque sei que ele e o meu interlocutor são inimigos fidagais.

A diferença entre essas duas séries de exemplos citados é que, enquanto os primeiros são mais explícitos, estes são mais velados, além do que, aqueles podem comportar uma expressão verbal que os explicite ou acompanhe. Assim, podemos estender os braços e dizer: "Queira entrar primeiro", bem como simplesmente proferir as palavras sem que o gesto as acompanhe. Já no segundo caso, dificilmente a palavra oral teria lugar. Podemos mentalizá-las mas jamais explicitá-las dizendo: "Escute, não vou passar por lá porque sei que aquele lugar lembra-lhe o acidente em que você perdeu seu pai e quero poupar-lhe esse desgosto" ou "Vou procurar comer mais devagar para acertar os. passos com você que, de tanto falar, está meio atrasadinho" Seria uma descortesia que deporia contra a inten- 
ção inicial, qual seja, a de tomar ou deixar de tomar uma atitude em sinal de deferência para com outrem. O tratamento, nesse caso, só tem sentido à medida que fica subentendido, oculto na consciência do seu autor.

Concretizando-as em palavras ou não, é fato que todas as situaçð̃es comportam uma verbalizaçao. $O$ homem tem o dom da palavra, e é por ela que também pode expressar tratamentos que um gesto ou uma expressão do rosto não são suficientes para transmitir. Ressalvados determinados momentos em que "os olhos dizem mais que a boca", são as palavras que, em regra, se não se prestam melhor para, servem para explicitar mais claramente o tratamento pretendido pelo elocutor. As palavras podem mentir e exprimir exatamente o contrário daquilo que o seu dono pretende, mas esta é uma questăo que implica na veracidade da relação entre a intenção do elocutor e sua ação verbal, que gostariamos de deixar para ser vista em uma outra oportunidade.

Do ponto de vista da forma de sua expressividade, o tratamento pode ser classificado em três categorias:

1. tratamento lingü ístico - quando a forma lingüística basta por si para constituir a expressão do tratamento dentro de um dado contexto. Referimo-nos ao emprego de pronomes de tratamento; de formas perifrásticas, notadamente no imperativo como uma forma de atenuar a ordem ou o pedido ("queira aguardar" em vez de "aguarde"l); do emprego do futuro do pretérito no lugar do indicativo ("pediria que" em vez de "peço que"), etc.

2. tratamento paralingü ístico - quando um ato com matizes de tratamento pode ser explicitado ou acompanhado por formas lingü ísticas acessórias, ou vice-versa. São aqueles casos a que nos referimos anteriormente, como sendo do primeiro grupo.

3. tratamento indireto - referimo-nos àqueles casos que, salvo na idéia do autor da ação, sua transparência como tratamento é muito tênue. Como vimos, sua verbalização perde o caráter de tratamento, neutralizando a intenção do seu autor que é a de, evitando ou praticando determinados atos, poupar sutilmente o outro de experiências desagradáveis.

Dessas três categorias, gostariamos de nos ater à primeira e ver 
como esses tratamentos lingüísticos funcionam como símbolos dentro da língua japonesa.. Já tivemos a oportunidade de nos referir ao tratamento da língua japonesa como um fenômeno lingüístico com um modelo teórico específico, sistematicamente elaborado, o que tem levado muitas vezes a interpretações errôneas de que a linguagem de tratamento constitui uma das caracteristicas desta língua $\left({ }^{*}\right)$. E essa sistematização, existente já de longa data, como atestam os primeiros documentos escritos do século VIII que, talvez por sua complexidade e variedade, dá a falsa idéia de ser particular da língua japonesa. A esse respeito notavam os jesuítas portugueses do século XVII que "toda a elegancia desta lingua consiste em saber usar de varias honras \& particulas que para isso tem dado a cada cousa seu lugar" e que "isto que toca as honras e cortesias tem muytas cousas particulares que melhor se aprendem com 0 uso que com preceitos" (2).

Em japonês, a forma lingürstica do tratamento é empregada pelo emissor, levando-se em conta a distância social ou psicológica que se estabelece entre ele e as demais pessoas implicadas numa situação de discurso (o receptor e as terceiras pessoas referidas), distância essa que é determinada por fatores extra-lingüisticos tais como a idade, o sexo, a posição hierárquica das pessoas em questão, bem como a intimidade, a animosidade, a relação de dívida porventura existentes entre elas $\left(^{*}\right)$. Assinala o Padre Rodriguez que " (d)estas honras respeitam(ndo) sempre, quem fala, aquem se fala, diante de quem, e de que cousas: por que tudo isto he necessario".(3)

Temos notícia, no entanto, de línguas que apresentam um sistema do tratamento muito próximo ao do japonés. Por exemplo, tanto o javanês, quanto o coreano, dispõem das três categorias básicas de tratamento que o japonês também comporta os quais veremos a seguir sendo que o seu uso é determinado pela relação entre a posiçăo hierárquica e a idade dos interlocutores no javanês, e pela relação entre a idade, a posição hierárquica, o grau de intimidade e os sentimentos de animosidade ou de manha dos interlocutores e as terceiras pessoas referidas, no caso do coreano. (4)

As expressర̃es de tratamento, KEIGO em japonês, significam literalmente "termos (GO) de respeito (KEI)" A classificação mais tradicional divide os KEIGO em:

1. SONKEIGO, literalmente "termos(GO) de veneração(SONKEI)"

2. KENJŌGO, literalmente "termos(GO) de modéstia (KENJO)" 


\section{TEINEIGO, literalmente "termos(GO) de polidez(TEINEI)"}

Enquanto os dois primeiros se referem às expressões utilizadas pelo emissor com relação às pessoas que atuam no seu discurso (o receptor, ele próprio ou as terceiras pessoas referidas), o último constitui uma forma de tratamento dirigida exclusivamente ao receptor, enquanto e somente receptor.

O emissor manifesta a sua consideração com relação à pessoa que se coloca numa posição superior à sua, seja por questões de ordem social, seja de ordem psicológica, através de duas formas diferentes: atribuindo SONKEIGO (expressão de respeito) quando a própria pessoa enfocada pelo emissor é o, sujeito ativo ou passivo da açăo verbal, e atribuindo KENJŌGO (expressão de modéstia) quando o sujeito da ação é uma pessoa inferior àquela que é o objeto do tratamento (5)

Pelo TEINEGO (expressão de polidez), o emissor endereça a sua mensagem de forma polida ao seu interlocutor, momento em que já não entra mais em jogo a relação de força existente entre eles. Essa tensão,se há e se sua explicitação se faz necessária, é expressa num momento anterior, a nivel de transmissão da mensagem. $\left(^{*}\right) 0$ receptor pode, portanto, receber do is tipos de tratamento num mesmo discurso: um enquanto sujeito ativo ou passivo da ação inserida na fala, e outro, enquanto um dos sujeitos da elocução.

Temos então, em primeira instância, dois significados amplos do tratamento da língua japonesa. Um, que revela a consideraçào do emissor em relação ao distanciamento que o separa da pessoa enfocada, devido a determinados fatores que marcam esse distanciamento e que não estão sob seu controle. Outro, que expressa a atenção do emissor para com o seu interlocutor, não dentro de uma relação de forças, mas apenas e tão somente dentro de uma relação de cordialidade.

Motoki Tokieda rotula o SONKEIGO e o KENJŌGO como "tratamentos objetivos" e O TEINEIGO, como "tratamento subjetivo" O seu modelo teórico alicerça-se em duas colunas basilares: termos nocionais ou objetivos, e termos formulativos ou subjetivos da língua japonesa. Termos nocionais ou objetivos sao aqueles cuja substância do conteúdo passa por um processo de conceptualização antes de serem expressos; podem expressar como uma noção ou um conceito, os seres do mundo material, bem como os sentimentos subjetivos pela sua objetivação. Já os termos formulativos ou subjetivos são aqueles que expressam diretamente atitudes subjetivas do emisor 
como os sentimentos, o julgamento, os desejos, sem passar por um processo de conceptualização.(6)

Para Tokieda, SONKEIGO e KENJŌGO constituem "tratamentos objetivos" por se relacionarem à expressão da substância lingü ística ou a conceitos que não dependem do subjetivo do emissor, uma vez que há ditames independentes da sua vontade que os determi. nam. O TEINEIGO é um "tratamento subjetivo" pois seu uso está na dependência da opção individual do emissor; nada há de exterior que o obrigue a usá-lo a não ser a vontade deliberada de transmitir a sua cortesia ou cordialidade ao receptor da sua mensagem.(7)

O distanciamento a que nos referimos acima é ditado por uma série de fatores que marcam o lugar que cada um dos sujeitos do discurso ocupa numa determinada situação. Esses fatores estão baseados nos valores criados e seguidos por aqueles que vivenciam uma determinada comunidade social, um determinado grupo cultural. No caso do tratamento japonês, esses fatores podem ser de ordem social ou psicológica. No entanto, o tratamento lingüístico nào revela em bruto esses valores, apenas o seu resultado, qual seja, a distância que o emissor estabelece entre si e as demais pessoas, segundo uma ponderação dos valores em jogo naquela relação. Se, por exemplo, o emissor é mais jovem e ocupa uma posição inferior na escala hierárquica social (supondo que ele é um auxiliar de escritório que se dirige ao chefe de seção), atribuirá aos atos por ele praticados os termos de modéstia, levando em conta a sua idade e o seu status social, inferiores em relação aos do seu interlocutor. Mas não estará expressando a diferença de idade ou de status em si. $O$ referente, no caso, é a distância social que o emissor determinou, levando em conta os fatores que ele considerou substanciais.

As expressões de tratamento sempre constituíram expressões lingüisticas que revelam uma forma qualquer de distanciamento. 0 que tem se modificado. no correr dos tempos, são os valores que o norteiam, conforme a sociedade que os comporta tenha alterado seu "modus vivendi", seu "modus pensandi", sua visão de mundo.

Apesar de os primeiros contatos com a cultura chinesa terem se estabelecido por volta do século III a II A.C., o Japão terá de esperar até $o$ século $V$ da nossa era para receber e assimilar a escrita ideográfica. É a primeira escrita de que tem conhecimento e passa a adotá-la como sua ortografia, com certas adaptaçð̃es fonéticas e semânticas, necessárias e inevitáveis no momento da sua adoçăo.

No início, o uso da escrita ideográfica era reservado a textos pro- 
duzidos no Japão mas cuja sintaxe e semântica obedeciam ao modelo chinés. A sua adaptação à sintaxe japonesa só ocorre por volta dos séculos VII e VIII, de forma que a análise que faremos do tratamento japonês e do seu significado será feita a partir de dados obtidos por esses textos até os de hoje.

Os textos desta época já registram expressões de tratamento e até hoje, apesar das mudanças de ordem lexical, morfológica ou situacional que se deram, podemos afirmar que a sua sistemática permaneceu una. Houve épocas em que uma ou outra forma lingü isțica inexistiu, em que houve fusão de duas em uma, em que houve predomínio de uma sobre as demais, mas o modelo teórico não sofreu modificaçð̃es substanciais.

Adotaremos a divisão da história do tratamento japonês de Yutaka Miyaji (8), que vê três períodos de sua evolução, a partir das modificações verificadas na concepção dos valores subjacentes ao tratamento:

1. época clássica - do séc. VIII ao séc. XII

2. época medieval - do séc. XII ao séc. $X I X$

3. época moderna - do séc. $X I X$ até hoje

Se a época clássica se caracteriza, grosso modo, pela existência de um tratamento absoluto, baseado numa consciência mais ou menos fixa de classes, na época medieval assistimos ao nascer do tratamento relativo, consagrado nos tempos atuais, onde a relatividade das relações sociais é marcante. Cumpre notar que o nascimento dos valores culturais que subjazem ao tratamento e da consciencia que - regula, são anteriores à sua consagração pela língua. Gostariamos de analisar quais foram esses valores que determinaram, ou ao menos marcaram os vários tratamentos no correr dos séculos, revelando significados diferentes conforme cada época.

A origem do tratamento se perde no tempo e várias sảo as teorias que especulam a este respeito. Uns a dâo como sendo a manifestação do respeito aos deuses, ao imperador, à natureza ( $Y$. Yamada e $H$. (zui); outros, como a manifestação da diferença de classes baseada na oposição respeito/desprezo ( $M$. Tokieda); outros ainda, como o resultado do sentimento muito sensível do homem japonês em relação a coisas e pessoas ( $K$. Hasegawa) ou como a marca do tabu do homem primitivo em relação à língua (K. Kindaichi e $T$ Tsujimura).

Não convém buscar uma origem única mas, se olharmos para a sociedade japonesa primitiva, sabemos por referência em livros históricos chineses que, por volta do século III, já havia diferença de clas- 
ses, que havia uma forma de poder centralizado rudimentar, exercido por magia (9), bem como que por volta do século V-VI (10), época de surgimento do Japão como nação, formava-se a classe aristocrática dominante, em torno da pessoa do imperador deificado.

O Japão não foge à regra e como toda sociedade primitiva, era uma sociedade com acentuada adoração a deuses. Apesar da existência de um poder centralizado, a deificação do imperador foi um meio que se encontrou para o seu fortalecimento e nasce a figura do imperador-deus. Não havia uma estratificação social diferenciada mas já havia uma separação nitida entre a classe dominante - a dos nobres que detinham o poder: os senhores locais, os conselheiros ou membros da família imperial - e a dominada - a dos trabalhadores, agricultores e artesãos na sua maioria, e que sustentavam esse poder.

Como resultado da veneração aos deuses, cria-se um tabu lingüistico: era vedado dirigir-se diretamente aos deuses, inclusive ao imperador; era necessário servir-se de eufemismos, por meio de palavras de ornamento. E a tese do aparecimento do tratamento em virtude do tabu lingüístico em relação aos deuses. Os textos do século VIII são ricos em tratamentos atribuídos a deuses e imperadores deificados, a quem eram empregadas expressర̃es do mais alto respeito, em toda e qualquer ocasião, independentemente da situação de discurso. São tratamentos dirigidos a seres de poder absoluto e incontestável, como o eram os deuses e o imperador na concepção desse povo.

Encontramos ainda nessa época, exemplos de auto-respeito protótipo do respeito absoluto - por parte do imperador e das pessoas com posição hierárquica bastante elevada. A eles era permitido referir-se a si próprios por meio de expressões de respeito em determinadas situaçōes: quando a diferença hierárquica entre as pessoas envolvidas era marcante, ou quando havia necessidade de enfatizar a diferença social como nos momentos em que se comunicava publicamente uma ordem baixada pelo imperador ou pelo poder central.

0 tratamento tinha nas suas bases um modelo de classes sociais fundado na consciência que seus usuários tinham da oposição respeitoso/desprezivel. Se de um lado, as pessoas de baixa escala social se referiam d̀s pessoas superiores por expressões de respeito, ao se referir a si próprios, o faziam por expressóes de modéstia. Respeito e modéstia constituem o verso e o reverso de uma mesma moeda, ambos são a expressão de um tratamento dispensado de baixo para cima e são as duas únicas formas de tratamento registradas nos documentos da época. 
Pelo que se pode depreender do seu uso, a nocão de extrato social era fixa, rígida e absoluta. As classes sociais mais elevadas recebiam sempre um tratamento respeitoso, năo importando qual fosse a relaçశ̃o que se estabelecesse em cada situaçăo. Acreditamos năo poder ignorar a força do fator psicológico que governa determinadas situaçర̋es de ódio, de briga ou de discussão, mas no que tange à documentaç̃o em textos, inexistem registros dessa natureza. Há um claro predomínio do fator social sobre o psicológico.

Talvez o fator social bastasse para dirimir qualquer dúvida no atribuir um tratamento mas tudo năo passa de suposiçăo. Deixando de lado o provável, o certo é que o tratamento existe desde que se tem conhecimento documentado da Ilngua japonesa e que, no in icio, ele simbolizava um respeito absoluto das pessoas por um poder religioso e/ou político, revelando a existência de uma forte consciência classista na época.

Se podemos caracterizar o tratamento do período clássico como um tratamento absoluto, atualmente vivemos a época do tratamento relativo por excelência. Enquanto aquele é movido por fatores sociais, mais objetivos e externos ao sujeito do discurso, neste predominam os fatores psicológicos, mais subjetivos e internos ao individuo, embora dele não possamos simplesmente excluir o social.

Entre ambos, temos um longo perfodo de transição (séc. XII ao séc. $X|X|$ que corresponde aproximadamente à Idade Média e PréModerna do Japão. E uma época de grandes conturbaçס̃es internas que marcam o aparecimento de novas classes sociais - a dos guerreiros (samurai) e a burguesia.

O aparecimento da classe guerreira e sua ascensão é marcada por uma infinidade de lutas que prosseguem mesmo depois de implantado o Shogunato, o governo do General issimo. Instalado como um simples posto militar, o shögun vai adquirindo forças até acumular o poder de fato em suas mãos, formando um governo paralelo ao governo central exercido pelo imperador e pela nobreza. Houve épo. cas em que representantes estrangeiros eram recebidos pelo shōgun, mas não pelo imperador, tamanho era o poder que adquirira.

O Japão assistiu a séculos de lutas internas que dividiu o pals em um incontével número de clãs, até ser a duras penas unificado por leyasu Tokugawa, no século XVII. Em meio ao caos social reinante, ascende a nova classe da burguesia por volta dos séculos XIV a XVI, trazendo uma nova inversão de valores.

E nessa época conturbadíssima e sacudida por lutas infindáveis 
que também o tratamento da língua japonesa passa por muitas transformaçōes.

O germe do tratamento relativo surge ainda na fase do predominio do tratamento absoluto. Começa com o registro das distinções feitas, principalmente na parte narrativa dos textos, quanto ao grau de respeitabilidade dos tratamentos: tratamentos mais elevados à família imperial, e outros menos elevados a nobres, desde que ocupassem uma determinada posição na escala social. 0 parâmetro que determina as regras do seu uso não mudou, continua sendo a diferença de estratos sociais. No entanto, apesar da relação hierárquica das pessoas implicadas ainda exigirem um tratamento específico, já nåo há aquela rigidez verificada até então.

Lançado o germe da relatividade do tratamento em meados do período clássico, auge da oligarquia aristocrática (por volta do século X), ela se desenvolve nos fins desse perfodo até assistirmos ao aparecimento das chamadas expressర̋es de polidez, tratamento relativo por excelência, na época medieval.

Uma forma de construir novas expressōes de respeito e de modéstia pela coadjuvação dos prefixos $\mathrm{O}, \mathrm{GO}, \mathrm{ON}$, ganha um grande impulso nessa época, o que propicia a passagem de certas expressōes de modéstia para um uso como polidez. Salvo quando a situação é muito clara em termos de diferença hierárquica e exige o emprego da modéstia, esta passa a desempenhar gradativamente o papel canalizador da consideração do emissor ao receptor enquanto receptor, independente da diferença hierárquica existente entre eles. Caracteriza exatamente a passagem do tratamento reverencial ao tratamento situacional ou da sociabilidade, que é o traço distintivo do tratamento moderno.

E difícil precisar a época dessa transição mesmo porque ela se deu no correr de vários anos, até de séculos. Outra razão de sua imprecisão reside na complexidade da relação social vigente. De um lado, houve a ascensão da classe dos guerreiros, mas na sua ascensão precisava de modelos da classe dominante para a aquisição de sua cidadania e posterior tomada do poder, tendo pois, adotado uma hierarquização tão ou mais rígida que a dos nobres. Essa é uma das razões pelas quais o tratamento absoluto continua a existir e ser profundamente utilizado.

Com o declínio da classe guerreira, desgastada por tantas e tão longas lutas, a burguesia começa a adquirir poderio econômico, o que the permite enfrentar os guerreiros, mas seus efeitos ainda não 
se refletem no uso do tratamento. Dentre as classes emergentes da época medieval (guerreiros e comerciantes) havia uma estratificação relativamente rígida que fora imposta pelos guerreiros, a classe dominante de então, e abalizada pela nobreza.

As camadas mais baixas do estrato social obedeciam às normas de tratamento, lingüístico e não lingüistico, estabelecidas pelos nobres e guerreiros, mas somente em relação a estes pois, entre si, começam a fazer uso de tratamentos diferenciados. Com a ascensão da burguesia, muda o padrão de vida social, desenvolvendo-se um tipo de vida comunitária, de vida citadina. Há um intercâmbio maior entre as pessoas, o que provoca a necessidade de maiores cuidados nas relações interpessoais e isso, naturalmente, consagra de vez o emprego das expressões de polidez. A relação de forças não é estabelecida somente dentro das classes detentoras do poder; ela passa também a existir nas demais classes mas baseadas em diferenças individuais, resultantes do maior poder aquisitivo, do poderio econômico e da posição social superveniente, o que a torna mais fluida e móvel que a resultante da estratificação social.

Em suma, a época medieval japonesa viveu muitas transformações: ascensão de novas classes emergentes, inversão de valores, lutas internas para assegurar o poder, e pelo poder, conquistar o reconhecimento das classes já institu ídas. E uma época em que o novo convive com o antigo, em que novas formas de vida e de valores procuravam alcançar sua cidadania, apoiadas nas já existentes.

E o que simboliza o tratamento dessa época?

E difícil definir pois várias e variadas são as formas de tratamento vigentes, reflexo, talvez, do caos social reinante. $O$ povo vivia novas experiências de estrutura social, mas muito preso ainda aos valores herdados de épocas anteriores. Se temos determinados usos que nada mais são do que a reiteração do tratamento absoluto da Antiguidade, temos outros nunca vistos antes, como as expressões de polidez e de ornamento, de que trataremos adiante.

Lançados os alicerces do tratamento atual nessa fase de transição, suas características vão sendo consolidadas. $O$ predomínio da verticalidade da relação humana como fator determinante do tratamento da Antiguidade, passa a ceder ao predomínio da relação lateral, de cordialidade. Deixam de ser seguidos os ditames impostos por uma escala hierárquica vertical para seguir os parâmetros de uma sociabilidade reciproca, no sentido horizontal, entre as pessoas envolvidas numa situação de fala. 
Não podemos ignorar a presença do status como um dos fatores determinantes do tratamento moderno, mas ele não passa de um dos, nåo o predominante. Mais fortes que o status, encontramos nas consideraçర̋es tecidas pelo emissor ao conferir um tratamento, as relaçőes de intimidade/não intimidade, de receber/prestar favores, a preocupação em manter a elegância ou a dignidade de suas palavras. A noçăo da diferença de status ainda persiste na consciência do emissor mais por uso e costume do que por uma intenção de expressar o respeito em si.

Em outras palavras, o emissor hoje está mais preocupado em demonstrar uma polidez ou uma cortesia, em não ser indelicado ou grosseiro nas suas falas, do que em marcar a distância social que o separa da pessoa enfocada. Por outro lado, não se pode ignorar que fatores de ordem social ainda têm um poder decisivo na definição do tipo de tratamento a ser atribuído. Só deixam de ser símbolo de veneração ou de respeito como antes, para servirem de parâmetro para se estabelecer a distância pela qual se possa manifestar a polidez, a cortesia. Se antes o termo KEIGO significava, literal e realmente, "expressões de respeito", hoje seria mais propriamente traduzido por "expressర̃es de cordialidade" ou "de sociabilidade"

Aquele respeito que as condiçőes sociais de estratificação exigiam passa a ser governado por uma vontade do emissor em expressar sua intimidade em relação à pessoa a quem o tratamento é dirigido. Não só a intimidade mas, muito ligada a essa idéia, há a noção de interioridade/exterioridade, oposição que hoje determina a atribuição ou não de formas de tratamento. $O$ emissor faz uma seleção das coisas e pessoas que estão dentro do seu mundo: os seus pertences, seus familiares, seus amigos mais chegados, as pessoas que compartilham com ele o mesmo tipo de atividade. Os demais se colocam fora desse universo e por isso têm o tratamento respeitoso que merecem.

O "eu" faz parte desse universo e assim como eu me trato com modéstia ou humildade em alguns casos e com polidez quase sempre, em relação d̀s demais pessoas da fala (portanto externas a mim), devo distinguir as coisas que estão no meu universo em relação àquelas que se colocam no mundo dos outros.

Nesse estado de coisas, surgem as expressőes de ornamento a que nos referimos antes. Suas raízes estão nos prefixos de respeito e em algumas expressões de modéstia da Antiguidade, mas o seu desgaste pelo uso e pelas mudanças sócio-culturais ocorridas nos séculos posteriores, fizeram com que fossem perdendo a carga de respeito origi- 
nal e passassem a ter apenas uma função estética pela qual tornava graciosa a sua expressão. $O$ belo procurou recuperar parte da dignidade perdida pelo tratamento com o desgaste. É um fenômeno que tem a sua forma embrionária nos meados da Era Medieval, desenvolve-se pelos seus fins, para se instituir na Era Moderna.

$\mathrm{Na}$ medida em que sua função é apenas estética, essas expressōes não se relacionam diretamente com nenhuma das pessoas da fala. São formadas, principalmente, pelo acréscimo dos prefixos $\mathrm{O}$ e $\mathrm{GO}$ a substantivos cujos referentes não pertencem, nem ao emissor, nem ao receptor, nem à terceira pessoa referida. Assim, quando eu digo "quero água", não estou me referindo à minha água, nem à tua, nem à ágúa de Fulano. "Agua" é tomada no sentido impessoal, como algo sem dono, que está por aí para todos e para ninguém. É diferente de "teu pai telefonou" O "pai" é do receptor e como tal deve ser tratado, ou seja, de maneira respeitosa, porque além de ser mais idoso que eu, provavelmente, é o pai do meu interlocutor, alguém que está fora do meu universo. Ao empregar o mesmo prefixo $\mathrm{O}$ a ambos os substantivos, o emissor está fazendo uso de uma expressão de ornamento no primeiro caso, e de uma expressão de respeito, no segundo.

Quando o emissor procura manter a distinção do seu discurso "enfeitando" um dos seus termos, está indiretamente expressando a polidez ao interlocutor, na medida em que está "enfeitando" a fala que o tem como receptor (11). A diferença entre as duas espécies de tratamento é que, enquanto as expressões de polidez constituem partículas pospostas à mensagem a ser transmitida, com o intuito único e expresso de formular a consideração do emissor ao seu receptor, as expressões de ornamento aproveitam um dos elementos impessoais inseridos na fala, para serem enfeitados ou atenuados e com isso, servirem de canal de transmissão dessa consideração. Aquelas seriam o papel com que se embrulha um presente e estas, um perfume que se acresce a um suéter ao devolvê-lo a quem o emprestou.

Função semelhante à das expressões de ornamento exercem determinadas expressões, antigamente de modéstia, que exprimem a consideração do emissor ao receptor, permeada pelos atos ou fatos inseridos no seu discurso. Além de o emissor se dirigir cortesmente ao receptor pelas expressões de polidez, ele aproveita determinados termos de sua fala para aumentar a carga do seu tratamento. Esses termos são em número limitado e se referem a algumas ações (ir, fazer, dizer, saber) bem como a alguns prefixos, todos originariamente de modéstia. $O$ limite que separa as expressões de modéstia dessas 
de polidez, que denominaremos "polidez reforçada", é muito tenue. As de modéstia se distinguem por não serem substituíveis sem que deixem de ser de modéstia, enquanto as de polidez reforçada podem ser substituídas por outros termos com grau zero de tratamento sem que com isso o emissor seja indelicado no tratar as pessoas.

Tendo surgido por volta do século XIII, seu uso está em declínio apesar de algumas resistências. Mas o emprego abundante das expressões de polidez propriamente ditas e um aumento considerável das de ornamento, parecem fadá-las à extinção.

E assim, temos hoje cinco espécies de tratamento em uso: dois tratamentos nocionais ou objetivos (as expressofes de respeito e de modéstial e três formulativos ou subjetivos (as de polidez, de ornamento e de polidez reforçada). Estamos numa fase de franco dominio do tratamento formulativo ou subjetivo. Começa a haver uma preocupaçåo maior do emissor com relação à situação de discurso, principalmente ao outro sujeito do discurso, a quem o tratamento é atribuído mais diretamente, filtrado por avaliaçðes subjetivas e individuais.

0 "respeito" não significa mais aquele respeito pela posição hierárquica superior da pessna referida. $O$ respeito não é mais símbolo direto de status social superior, mas deferência do emissor por uma pessoa, hierarquicamente superior sim, mas sem ter como referente a diferença hierárquica em si. A hierarquia social é apenas uma medida para o emissor estabelecer o distanciamento psicológico e subje. tivo em relação a essa pessoa; não é o conteúdo do significado.

NOTAS:

(") Para maiores esclarecimentos, consultar o artigo "Breves considerações sobre as expressరóes de tratamento da IIngua japonesa", publicado na revista "Estudos Japoneses - vol. 3", do Centro de Estudos Japoneses, 1983.

(1) C.K. Ogdens e I.A. Richards, "O Significado de Significado", p. 31.

(2) Pe. loão Rodriguez, "Arte da Lingoa de lapam" p. 168 (p. 339 da cópia xerografadal.

(3) Idem, p. 158 (p. 319 da cópia xerografada).

(4) Cf. Hiroyuki Umeda, "Chōsengo no Keigo" e Osamu Sakiyama, "Jawago no Keigo"

(5) Essas expressర̋es podem ser atribu Idas também a objetos ou coisas referentes à pessoa enfocada, bem como às pessoas e coisas que pertencem ao universo do emissor (Ver p. 12 deste artigo). 
(6) Refere-se às partículas formulativas (gramêmicos) da língua japonesa que formulam a manifestação subjetiva do emissor em relação ao seu enuncia. do (V. "Sobre a Estrutura da Lingua Japonesa" in "Estudos Japoneses vol. 1" 1979, p. 83).

(7) Dentro da mesma acepção, Toshiki Tsujimura os denomina, respectivamente, "tratamento relativo à substáncia" e "tratamento relativo d̀ pessoa"

(8) Yutaka Miyaji, "Keigoshiron", p. 23.

(9) Referência em "Gishi" (História de Wei) no seu capítulo sobre o povo de Wa, datado do século III. O povo de Wa, nome dado pelos chineses ao Ja. pão, "era governado por uma mulher . os homens de classe baixa, quando cruzavam com pessoas elevadas pelo caminho, recuavam até o matagal à beira da estrada e, ou se agachavam, ou se ajoelhavam, e mãos postas no chão, demonstravam-lhes seu maior respeito"

(10) Os primeiros documentos históricos japoneses, "Kojiki" e "Nihonshoki" embora escritos no século VIII, fazem referências a fatos que ocorreram a partir do século $\mathrm{V}$.

(11) Alguns vêem a sua origem no linguajar empregado pelas cortesas dos sécu. los XIV a XIX. Na sua vida faustosa e refinada de corte, precisavam manter a dignidade que sua posição exigia e isso se fazia refletir na linguagem por elas utilizada.

\section{BIBLIOGRAFIA}

MALMBE RG, Bertil. Signes et Symboles. Paris, A \& J. Picard, 1977. MINAMI, Fujio et al. "Keigo no Taikei", in Keigo Koza - vol. 1: Keigo no Taikei. Tóquio, Meijishoin, 1974.

MIYAJI, Yutaka. "Keigoshiron" in Col. Nihongogaku 9 - Keigoshi. Tóquio, Meijishoin, 1981.

"Gendai no Keigo" in Col. Kokugoshi 5 -Keigoshi. Tóquio, Taishükan, 1971.

NISHIMIYA, Kazutami. "Jodaikeigo to Gendaikeigo" in Col. Nihongogaku 9 Keigoshi, supra citado.

OGDEN, C. K. \& RICHARDS, I. A. O Significado de Significado. Rio de Janeiro, Zahar, 1976.

ŌISHI, Hatsutarō. "Gendaikeigo no Tokushitsu, sono shōrai" in Col. Nihongogaku 9, supra citado.

RODRIGUEZ, Pe loão.: Arte da Lingoa de lapam. Nagasaki, Compania de IESV 1608 (cópia xerocada por Benseisha, Tóquio, 1976).

SAKIYAMA, Osamu. "Jawago no Keigo" in Keigo 8 - Sekai no Keigo. Tóquio, Meijishoin, 1974.

TOYAMA, Eiji. "Keigo no Hensen", in Col. Nihongo 4 - Keigo. Tóquio, Iwanami, 1977. 
TSUJIMURA, Toshiki. "Keigo Ishikishi", in Col. Nihongogaku 9, supra citado. "Keigoshi no Hōhō to Mondai" in Col. Kokugoshi 5, supra citado.

UMEDA, Hiroyuki. "Chōsen no Keigo", in Col. Keigo 8, supra citado. 